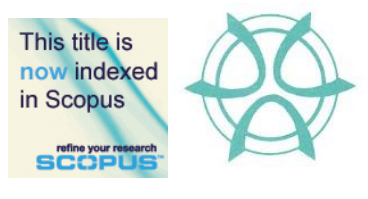

PLANNING MALAYSIA:

Journal of the Malaysian Institute of Planners

VOLUME 15 VOLUME 1 (2017), 389 - 396

\title{
SIDEWALK ACCESSIBILITY AT MELAKA'S TRADITIONAL STREETS FOR PEOPLE WITH DISABILITIES (PwDs)
}

\author{
Nor Haslina Ja'afar', Asiah Abdul Rahim², Nur Amirah Abd. Samad ${ }^{3}$, \& Che \\ Raiskandar Che Rahim ${ }^{4}$ \\ ${ }^{I}$ Faculty of Engineering and Built Environment \\ UNIVERSITI KEBANGSAAN MALAYSIA \\ ${ }^{2,3,4}$ Kuliyyah of Architecture and Environmental Design \\ INTERNATIONAL ISLAMIC UNIVERSITY MALAYSIA
}

\begin{abstract}
The accessibility of street as a social arena that fulfils the need for people with disabilities (PwDs) is an important consideration in the urban design of an area. With the rising number of PwDs in Malaysia, this aspect of street design is even more critical. This paper evaluates the accessibility level of sidewalk along Jalan Hang Jebat, Melaka to PwDs. On-site access audit simulation was carried out. Actual PwDs were engaged for the simulation. It was found that the sidewalk in inaccessible to PwDs due to presence of barriers and the design of the sidewalk itself. This paper suggest that the minimum requirement of MS1184:2014 must be implemented in the sidewalk design and the concept of 'shared space' can be adopted in the study area.
\end{abstract}

Keyword: Traditional street, accessibility, public space, access audit, people with disabilities (PwDs).

Date Received: $30^{\text {th }}$ April 2016

Date of Acceptance: $30^{\text {th }}$ October 2016 
Nor Haslina Ja'afar, Asiah Abdul Rahim, Nur Amirah Abd. Samad, \& Che Raiskandar Che Rahim

Sidewalk Accessibility at Melaka's Traditional Streets for People with Disabilities (PwDs)

\section{INTRODUCTION}

In urban design, street is an indispensable element in shaping a city. Lynch (1960) identifies street as 'path', which is one of the main elements of urban design. The importance of street can be seen from its appearance and its function as 'public open space' where it becomes a major node as an arena for various social activities such as relaxing, walking and chatting. Important streets generate their own individual character, which are mainly evident in old and traditional cities and towns (Abdul Rahim et al., 2014; Sulaiman, Shamsuddin \& Anwar, 2007; Bashiti \& Abdul Rahim, 2015).

Streets should also cater for the people with disabilities (PwDs). This is to promote similar level of accessibility to PwDs as to the general public. The consideration of PwDs' needs in street design is even more critical now, especially when the statistics from the Jabatan Kebajikan Masyarakat (Social Welfare Department) show an increasing trend in the number of PwDs in Malaysia (Bashiti \& Abdul Rahim, 2015). Similarly, Ja'far (2015) and Mohd Hussain et al. (2016) also state that the number of application for PwDs cards/passes in Malaysia is also increasing.

Abdul Rahim et al. (2014) propose that a sustainable design for accessibility should be considered in all of our physical development in order to make our cities world class. Accessibility in the built environment is increasingly relevant to Malaysia, not only to prepare for the ageing population and PwDs, but also for the whole population at large. In order to understand the best way to include the widest range of users it is necessary to recognise the range of abilities that must be served and hence to be able to prioritise their different needs (Harisson \& Dalton, 2013). Universal Design, having moved on from 'barrierfree' design, embraces more diverse needs than just providing for people with disability and recognises that in everyone's life course various forms of disability will be experienced, with differing degrees of seriousness. Perhaps one of the greatest advantages of adopting universal design principles is that they are inclusive of everyone, and not just providing for 'special needs' users or thinking merely of a 'barrier-free' environment.

In a more local context, Mohd Hussain et al. (2016) agree that the needs of PwDs have received attention from all parties since their number keeps increasing year by year. It is thus vital to provide proper planning and design guidelines to ensure that this group of people have the opportunity to access the environment (Ja'afar, 2015). Moreover, improved accessibility enhances the value of the built environment, thus creates a place or street that facilitates the people to have a better quality of life (Kose, 2014).

It is important that street environment, especially of the traditional streets, is accessible to all group of people including PwDs. Traditional streets are places of legacy. By having access to the streets, their legacy would be enjoyed and experienced by the people including PwDs and also tourists. Thus, 
PLANNING MALAYSIA:

Journal of the Malaysia Institute of Planners (2017)

this paper analyses the level of accessibility for PwDs to sidewalk of a traditional street design by referring to the minimum design requirements provided in Malaysian Standards MS1184:2014.

\section{METHODOLOGY}

Jalan Hang Jebat, which is located in the Historical City of Melaka, was selected as the study area. The Historical City of Melaka is one of the heritage site listed under the UNESCO World Heritage Sites. The Jalan Hang Jebat is a popular street in the City, which is frequented by locals and tourists alike. The street is lined with old shophouses on both sides. Sidewalks separate the street from the shophouses.

Data was obtained through access audit simulation, in which actual PwDs were employed to conduct the simulation on-site. Access audit is an examination of an existing building, including its facilities and services, against pre-determine criteria to assess its usability. The main objective of access audit is to study the accessibility level of a place (in this study, Jalan Hang Jebat) in order to aid the planning, design and improvements so that the objective of inclusive and universal use may be achieved (Mohd Hussain et al., 2016; Jabatan Kebajikan Masyarakat, 2014).

The simulation was carried out with actual disabled persons from three categories; elderly (including frail person), visually impaired and mobility impaired persons. These three categories were selected because they are the most significant category of the PwDs (Harrison \& Dalton, 2013; Shamsuddin \& Sulaiman, 2008). The objective was to test how well the outdoor street environment performs in terms of access and ease of use by these groups of users. Six PwDs were engaged for the simulation, with two PwDs per category. They are well trained in conducting access audit and simulations identify the types of barriers and dangers to PwDs in an area that may be unforeseen by urban designers, architects and city planners.

Checklist form was pre-prepared and used during the audit simulation. Elements of accessibility that were observed included curb cuts, tactile walking surface indicator (TWSI), pedestrian crossing and general obstructions. All identified problem areas were photographed as evidence and used in data analysis. Consequently, semi-structured in-depth interviews were conducted with the participants of the audit (the six PwDs) to gain information on their perceptions towards the accessibility level of the study area. Data from the simulations were compared to the Malaysian Standards MS1184:2014 in order to identify the level of accessibility. Colour codes were used to denote access level of the study area: (i) red (inaccessible), (ii) yellow (moderately accessible) and (iii) green (accessible). These approaches have been used by other researchers in conducting access audit simulation such as Zen, Abdul Rahim \& Abu Bakar (2012), and Ja'afar, Sulaiman and Shamsuddin (2012). 
Nor Haslina Ja'afar, Asiah Abdul Rahim, Nur Amirah Abd. Samad, \& Che Raiskandar Che Rahim Sidewalk Accessibility at Melaka's Traditional Streets for People with Disabilities (PwDs)

\section{RESULTS}

One of the main outputs of the access audit was a layout plan of the study area indicating the accessible routes along the Jalan Hang Jebat. For the study area, five main pit stops were identified along the street (Figure 1). The destination to each point was analysed, measured and marked. The results of the access audit are as in Table 1 below.

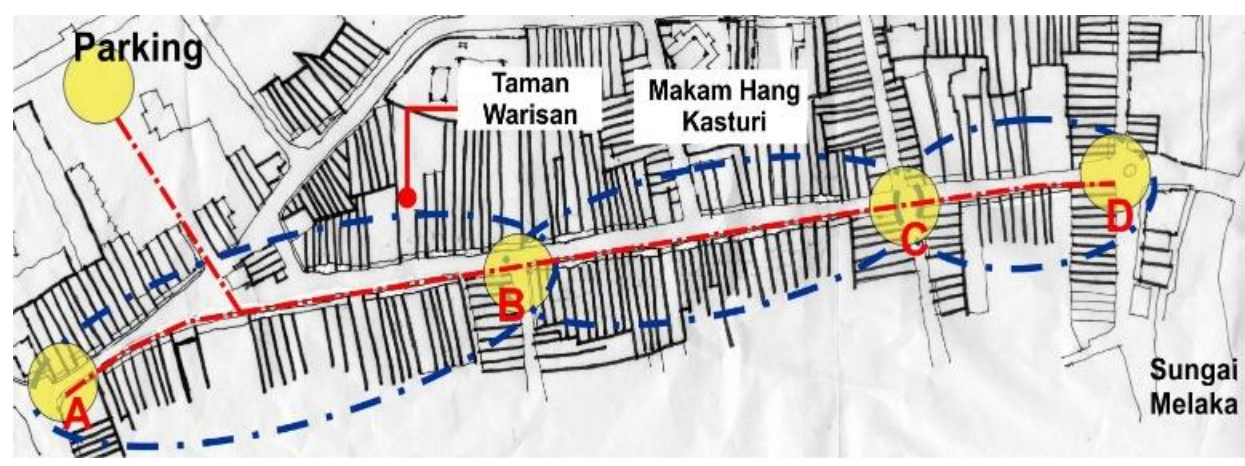

Figure 1 Journey of PwDs Base on 5 Main Stations

Table 1 Sidewalk Accessibility at Jalan Hang Jebat to PwDs

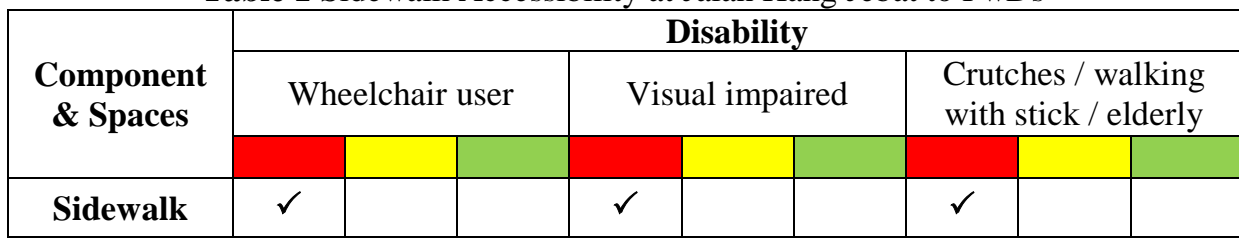

Legend:
\begin{tabular}{|l|l|}
\hline Level of Accessibility & Colour Code \\
\hline Accessible & \\
\hline Moderately accessible & \\
\hline Inaccessible & \\
\hline
\end{tabular}

Based on the access audit simulation, several obstructions were identified. It was found that the location of street lamps and vehicle that were parked on the sidewalk have obstructed the movement of PwDs (Figure 2) especially the wheelchair users and the visually impaired persons. According to the PwDs, "The location of lamp post in the centre of sidewalk obstructs the movement of people, especially the PwDs. There are also vehicles parked on the sidewalk and this irresponsible behaviour has created difficulties for people to walk along the sidewalk, especially PwDs. I think people who illegally parked their vehicles should be penalised."

Moreover, poorly designed and poorly maintained sidewalk also posed difficulties to the visually impaired persons and the wheelchair users (Figure 3). Poor design includes irregular width of the sidewalk, especially the portion where 
PLANNING MALAYSIA:

Journal of the Malaysia Institute of Planners (2017)

the sidewalk is too narrow. Width of sidewalk is also affected by peddlers and shop owners using the sidewalk to display their merchandise. Poor maintenance include broken surface of the sidewalk and missing tiles from the sidewalk surface.

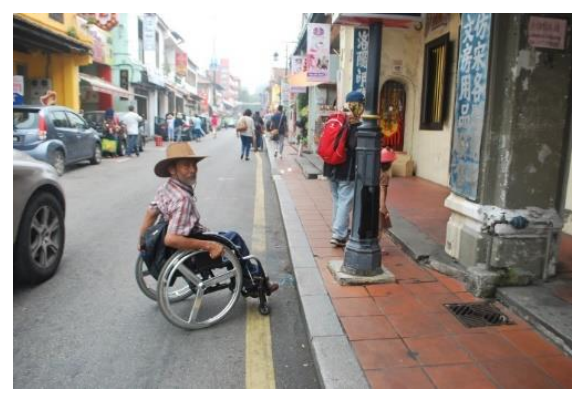

Figure 2.1 Obstructive Elements Along The Sidewalk: Lamp Post

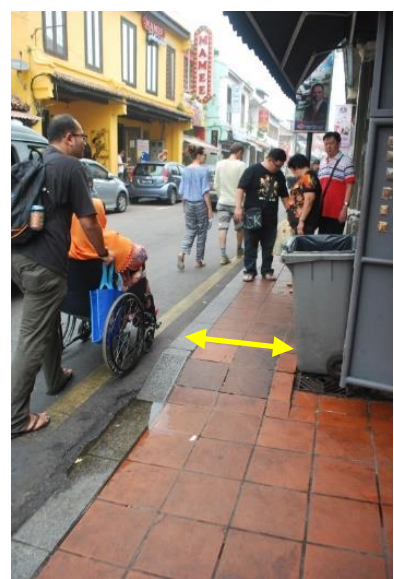

Figure 3.1 The Width of Sidewalk is Narrow at Some Locations

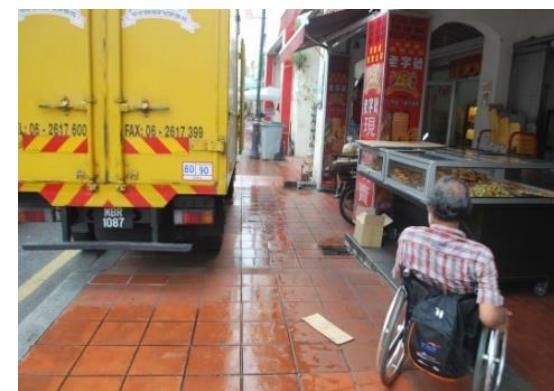

Figure 2.2 Loading Activities Obstructing the Accessibility of Sidewalk Especially for Wheelchair Users and Visual Impaired

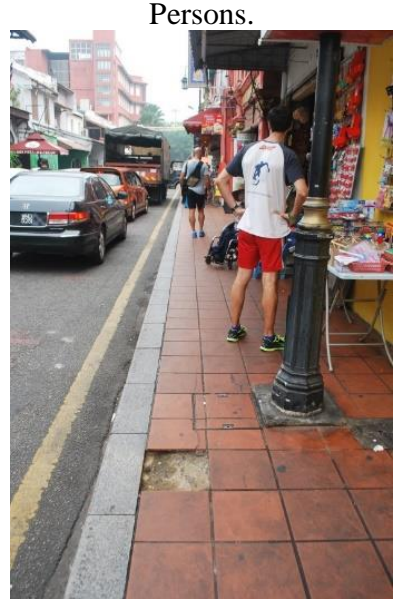

Figure 3.2 Poor Maintenance of Pavement Surface Create Barriers for PwDs

\section{RECOMMENDATIONS}

The information emerged from the access audit simulation indicates that the overall level of accessibility for PwDs at Jalan Hang Jebat is poor (inaccessible) especially for wheelchair users and visual impaired persons (Table 1). Thus, this paper recommends that the universal design approach based on the minimum requirements of the MS1184:2014 is implemented in the study area.

According to MS1184:2014, the clear minimum width of sidewalk should be $1500 \mathrm{~mm}$ (Department of Standards Malaysia, 2014) (Figure 4). Therefore, this paper suggests that the street lamps should be relocated away from 
Nor Haslina Ja'afar, Asiah Abdul Rahim, Nur Amirah Abd. Samad, \& Che Raiskandar Che Rahim Sidewalk Accessibility at Melaka's Traditional Streets for People with Disabilities (PwDs)

the sidewalk. At the same time, strict enforcement of traffic rules must be implemented to penalise and discourage people from parking their vehicles on the sidewalk.

The narrow width of sidewalk also obstructing the movement of the PwDs. One of the reason of narrow sidewalk in the study area is because of limited area. Thus, it is recommended that in cases where sidewalk width cannot be provided at the minimum of $1500 \mathrm{~mm}$, then sidewalk should not be provided at all. Instead, the concept of 'shared space' can be implemented where movement priority is accorded to pedestrians (Figure 4). Previous research shows that motor vehicles will slow down in shared space area because drivers will have to be aware of the pedestrian movement (MPMBB, 2010). In some cases, the 'shared space' can be transformed from street into pedestrianized area with limited vehicle access.

Other measures to improve sidewalk accessibility in the study area to PwDs must also be implemented. These include regular maintenance of the sidewalk and the restriction to shop owners and peddlers to use the sidewalk to display their merchandise.

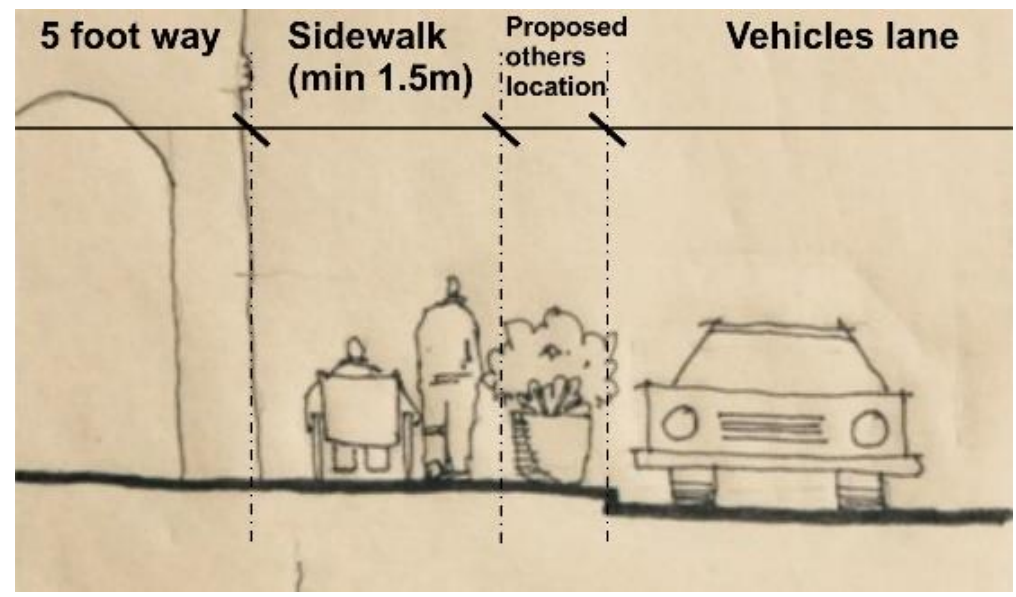

Figure 4.1 Minimum 1.5m width of sidewalk without any obstacle 
PLANNING MALAYSIA:

Journal of the Malaysia Institute of Planners (2017)

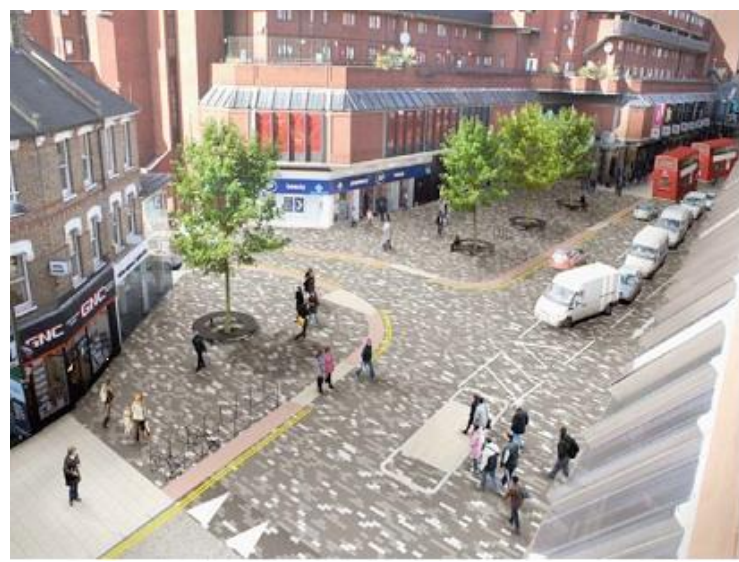

Figure 4.2 An Example of Shared Space Approach

\section{CONCLUSIONS}

This paper has shown that despite the provision of sidewalk in the study area, it is not accessible to PwDs because of the existence of barriers and obstructions on the sidewalk, as well as the design of the sidewalk itself. This paper recommends, among others, the implementation of 'shared space' concept in the study area in order to ensure accessibility to PwDs. At the same time, the access audit which was conducted with actual PwDs proved to be reliable and useful.

\section{ACKNOWLEDGEMENTS}

The authors thank Universiti Kebangsaan Malaysia (UKM) for the support of this research via research grant "GUP 2015-028". Appreciation is also accorded to KAED Universal Design Unit (KUDU) team for their assistance in data collection.

\section{REFERENCES}

Abdul Rahim, A., Zen, I., Abd. Samad, N. A., \& Che Rahim, C. R. (2014). Universal design and accessibility: towards sustainable built environment in Malaysia. In H. Caltenco, P. Hedvall, A. Larsson, K. Rassmus-Grohn \& B. Rydeman (Eds.), Universal Design 2014: Three Days of Creativity and Diversity, Proceedings of the International Conference of Universal Design - Assistive Technology Research Series (Volume 35) (pp. 299-306). Amsterdam: IOS Press.

Bashiti A., \& Abdul Rahim, A. (2015). A study on the accessibility in shopping malls for people with disabilities (PwDs) in Malaysia. International Journal of Natural Science Research, 3(1), 9-20.

Department of Standards Malaysia. (2014). Universal design and accessibility in the built environment - code of practice (2nd revision). Malaysia Standard 1184:2014.

Ja'afar N. H., Sulaiman A. B., \& Shamsuddin, S. (2012). The contribution of landscape features on traditional streets in Malaysia. In M. Y. Abbas, A. F. Ibrahim \& N. 
Nor Haslina Ja'afar, Asiah Abdul Rahim, Nur Amirah Abd. Samad, \& Che Raiskandar Che Rahim

Sidewalk Accessibility at Melaka's Traditional Streets for People with Disabilities (PwDs)

F. Nik Azhari (Eds.), ASEAN Conference on Environment-Behaviour Studies 2012 (pp. 1-14). Bangkok, Thailand: Universiti Teknologi MARA.

Ja'afar N. H. (2015). Karakter fizikal jalan tradisional; kajian kes di Melaka Bandaraya Bersejarah (Doctorate thesis). Universiti Teknologi Malaysia, Skudai, Johor.

Jabatan Kebajikan Masyarakat (2014). Statistik Jabatan Kebajikan Masyarakat 2014.

Harrison, J., \& Dalton, C. (2013). The familiar and the strange: the limits of universal design in the European context. In Proceedings of the $3 \mathrm{rd}$ International Conference on Universal Design in the Built Environment 2013. Kuala Lumpur: KUDU.

Kose, S. (2014). Tourism for all: how can universal/inclusive design accommodate senior travelers? Symposium on Trends in Universal Design 2014, December 1, 2014, Kuala Lumpur, Malaysia.

Lynch, K. (1960). Image of the City. London: The MIT Press.

Mohd Hussain, M. R, Tukiman, I., Zaidin, N., \& Mohd Shahli F. (2016). Campus landscape environment fot student with disabilities (SwDs) in IIUM. Journal of Universal Design in the Built Environment, 2(1), 37-51.

MPMBB. (2010). Rancangan Khas. Majlis Perbandaran Melaka Bandaraya Bersejarah.

Shamsuddin, S., \& Sulaiman, A. B. (2008). Lessons from traditional towns and cities for sustainable future places. In: A. B. Sulaiman \& M. M. Mai (Eds.), Urban design issues in the developing world; the case of Malaysia and Nigeria (pp. 1-174). Kuala Lumpur: Penerbit Universiti Teknologi Malaysia.

Sulaiman, A. B., Shamsuddin, S., \& Anwar, M. (2008). Gentrification process and place attachment in historical settlements: a case study. In Proceeding Regional Architecture and Identity in the Age of Globalization (Vol. 3) (pp. 1287-1298).

Zen, I., Abdul Rahim, A., \& Abu Bakar, A. (2012). Access audit in religious buildings and public spaces in old Damascus city, Syria. Kuala Lumpu: IIUM Press. 